\title{
Customer Engagement in Higher Education: How Important Role of Social Media Marketing, E-Service Quality, and E-Satisfaction for Generation Z Students?
}

\author{
Freddy Pandapotan Simbolon ${ }^{1 *}$; Lena Yanti ${ }^{2}$ \\ ${ }^{1,2}$ Management Department, BINUS Business School Undergraduate Program, Bina Nusantara University \\ Jl. Kebon Jeruk Raya No. 27, Kebon Jeruk, Jakarta 11530, Indonesia \\ ${ }^{1}$ freddysimbolon@hotmail.com; 2Ly_yun@yahoo.co.id
}

Received: $18^{\text {th }}$ January $2021 /$ Revised: $17^{\text {th }}$ February $2021 /$ Accepted: $17^{\text {th }}$ February 2021

\begin{abstract}
How to Cite: Simbolon, F. P. \& Yanti, L. (2021). Customer engagement in higher education: How important role of social media marketing, e-service quality, and e-satisfaction for generation $\mathrm{Z}$ students?. The Winners, 22(1), 15-23.
\end{abstract}

https://doi.org/10.21512/tw.v22i1.6970

\begin{abstract}
Thegoal of theresearch was to examine the effect of social media marketing, e-service quality, and e-satisfaction on customer engagement. The research was conducted at Bina Nusantara University (Binus) with a sample of 100 students from Generation $\mathrm{Z}$ using quantitative approach with data collection by distributing questionnaires to be analyzed using path analysis. The findings show that social media marketing and e-service quality significantly have impacts on e-satisfaction and customer engagement, while the e-satisfaction does not significantly impact customer engagement. Therefore, the development of digital technology in higher education becomes the main focus for supporting services and activities.
\end{abstract}

Keywords: customer engagement, social media marketing, e-service quality, e-satisfaction

\section{INTRODUCTION}

Industrial era has changed from industry 3.0, which is indicated by the rapid development of computers, to industry 4.0 characterized by the massive use of digital technology. Industry 4.0 is known as a technological transformation towards a physical-digital system in manufacturing which has a disruptive impact on the industry (Yu \& Schweisfurth, 2020). The widespread use of social media such as Instagram, Youtube, Twitter, WeChat, Facebook, and WhatsApp in various fields of life is concrete evidence of the existence of digital industry era. Currently, social media has not only been consumed by urban communities but has penetrated to remote villages. Social media is an online social networking platform as a means of communication and connection between individuals which has attracted billions of users (Wang, Liang, Mahto, Deng, \& Zhang, 2020).

Social media has been used extensively in supporting corporate business interests (Cheng \& Shiu, 2019; de Zubielqui \& Jones, 2020) since it is considered to have an important contribution in improving the efficiency of customer relationship management (Thomas, Orme, \& Kerrigan, 2020; G. Wang, Zhang, \& Zeng, 2019). Social media acts as a marketing tool to foster social interaction (Yang $\&$ Che, 2020) and brings many benefits, such as the ability to reach a wide audience, to drive sales through social commerce, and to build trust and reputation (Sharma \& Bharathi, 2013).

In the era of digital industry, customer engagement has a strategic role in achieving business success as an important transcendent relational idea. Besides, it is shown as a tool to develop and improve relationships with customers (Ting, Abbasi, \& Ahmed, 2020). Customer engagement has a significant place and plays an important role in understanding the consequences associated with customers, such as consequences related to loyalty (Graffigna \& Gambetti, 2015). Therefore, the company must keep striving for customer engagement as it creates a good relationship between the company and customers which leads to loyalty. It considered profitable for the company as it maintains the company's survival in the long run.

Customer engagement is a manifestation of customer behavior towards a particular company, brand or product that involves the company's efforts to empower and motivate customer contributions (Ting et al., 2020). Marketing Science Institute (2015) describes customer engagement as a manifestation 
of customer behavior towards brands outside of purchasing activities resulting from individual's motivation such as word of mouth, recommendations, interaction between customers, blogging, writing reviews and other similar activities. Meanwhile, according to So, King, and Sparks (2014), customer engagement is a marketing activity with orientation towards customer behavior and psychology.

Bowden (2009) explains the concept of customer engagement as a process functions, which is connected to the role of trust, commitment and involvement in creating loyal and engaged customers. Armstrong dan Kotler (2015) state that customer engagement makes brands a meaningful part of conversations and consumers' lives by encouraging direct and sustainable customer engagement in shaping conversations, experiences, and brand communities. Therefore, according to Solomon et al. (2012), customer engagement is important to find ways to keep customers involved in the business after sales are made through customer referral programs or other means.

Most of recent business field uses social media as a marketing activity, including higher education. Higher education has an important role in creating transformation to the digital industry, because of its position as an advanced research institution that plays an important role in building research and academic capacity that drives the national innovation system (Jung, 2020). Higher education can also play an important role in changing the landscape of digital transformation gradually and rapidly (Jackson, 2019), influencing the human capital development pathway (Pucciarelli \& Kaplan, 2016), providing important assurance of the quality of human resources through the creation and application of knowledge, as well as pillars important technological innovation and industrial transformation (Wu \& Liu, 2021).

One of the higher educations that have been actively utilizing social media is Bina Nusantara University (Binus). Instagram has been chosen to help develop communication and marketing under the account name of Gabung_BINUS. Instagram is an application for sharing photos and videos which, in Indonesia, has as many as 63 million users (Kemp, 2020). Social media marketing is an integrated element of $21^{\text {st }}$ century business that is useful for reaching new audiences and strengthening bonds with customers (Felix, Rauschnabel, \& Hinsch, 2017). The use of social media at Binus is an effort to strengthen customer engagement. However, based on the observations made on 144 Gabung_BINUS contents, it is known that student involvement remains low and less active due to a decrease by $37,4 \%$. It indicates that Gabung_BINUS Instagram has not optimally been managed to maintain and improve relationships with students as customers, so it has not been effective in strengthening student engagement.

OECD (2000) shows that student engagement is essential in influencing academic and career achievement. However, student engagement in various countries tends to be lacking. Students who are more involved on campus will have a better level of understanding the concept, and are considered the key to overcoming low achievement, student boredom and alienation, and dropout rates (Ahlfeldt, Mehta, \& Sellnow, 2005; Fredricks, Blumenfeld, \& Paris, 2004; Fredricks \& McColskey, 2012).

It must be realized that currently students are dominated by Generation $\mathrm{Z}$ born during the development of the digital era, which is characterized as digital native being technologically savvy (Bernstein, 2015; Priporas, Stylos, \& Fotiadis, 2017). Social media becomes part of their daily life (Ruangkanjanases \& Wongprasopchai, 2017). Therefore, the proper use of social media for both marketing and service activities plays an important role in strengthening student engagement from Generation $\mathrm{Z}$. This requires the campus to have adequate information technology support and competent staff to access and operate social media.

In the digital industry era, social media marketing has an important role in building customer engagement. Social media is an online service that supports social interaction between users through web or mobile-based publishing techniques which are accessible and extensible (Cheng \& Shiu, 2019). Social media uses advanced information and communication technology that offers users the ability to connect, communicate, and engage with other people (Bullini Orlandi, Zardini, \& Rossignoli, 2020; Kavota, Kamdjoug, \& Wamba, 2020). Social media is considered an effective channel to reach consumers at lower costs than conventional media such as print media, television, and radio (Iankova, Davies, ArcherBrown, Marder, \& Yau, 2019). By using social media, marketers have the flexibility to choose how to carry out marketing strategies, including consideration of messages and activities to be carried out (Ngai, Moon, Lam, Chin, \& Tao, 2013; Pham \& Gammoh, 2015). Social media also provides a wider choice of companies to make customers more aware, motivated to buy, and to build sustainable relationships with brands, so social media can be used as a tool to increase consumer engagement (Dissanayake, Siriwardana, \& Ismail, 2019). Social media has characteristics such as enabling bilateral communication and interaction as well as content creation that makes it different from traditional media (Shawky, Kubacki, Dietrich, \& Weaven, 2019), which is useful for social marketers to build lasting relationships with customers, and is effective in driving change of long-term behavior (Bannor, Asare, \& Bawole, 2017; Chen \& Shi, 2015). Ashley \& Tuten (2015) and Sashi (2012) have shown that the use of social media can encourage customer engagement. Apart from having an effect on customer engagement, social media marketing has also been identified as having an effect on satisfaction (Hanaysha, 2017; Zoubi \& Al-Harazneh, 2019). This leads to the first $\left(\mathrm{H}_{1}\right)$ and second $\left(\mathrm{H}_{2}\right)$ hypothesis.

$\mathrm{H}_{1}$ : Social media marketing significantly impact 
customer engagement

$\mathrm{H}_{2}$ : Social media marketing significantly impact e-satisfaction

The development of digital technology has an impact on how services to customers are also mostly done electronically (e-service). According to Elsharnouby and Mahrous (2015), to create an e-service quality concept, information technology is needed including the web, information kiosks and mobile devices. Quality service is also an important factor in encouraging customer engagement. Service quality is an advantage offered to customers to satisfy their needs (Keillor, Wilkinson, \& Thomas, 2007). Service quality is also related to the ability of a company or organization as a service provider to always improve the services to customers (Perry \& Thomson, 2004), and the ability to understand customer needs and to exceed their expectations (Hollins \& Shinkins, 2006) by showing totality, accuracy, and fulfilling what has been promised (Andrews, Boyne, Law, \& Walker, 2012). There are five common dimensions used to measure service quality in various industrial sectors including in higher education institutions, namely tangibles, reliability, responsiveness, assurance, and empathy (Zeithaml, Parasuraman, \& Berry, 1990; Chui, Ahmad, Bassim, \& Zaimi, 2016; Đonlagić \& Fazlić, 2015).

In higher education institutions, service quality shows the extent to which the service meet students' expectation (Sultan \& Wong, 2013). In general, students make assessment based on the perceived experience compared to their expectation (El Alfy \& Abukari, 2019). In other words, service quality indicates the difference between students expectations and the service perceived (O'Neill \& Palmer, 2004). Today's universities have also developed electronicbased services. The quality of electronic services shows the extent to which customer expectations are fulfilled by online service providers (Santos, 2003). Electronic service quality includes all services along with information, agreements, fulfillment, and postsales services (Xu, Zeng, \& He, 2017). Researchers have shown that e-service influences customer engagement (Dassanayake \& Senevirathne, 2018; VO, Chovancová, \& Tri, 2020). In addition, Chang, Wang, and Yang (2009), Nasution (2019), Ting, Ariff, Zakuan, Sulaiman, and Saman (2016), and VO et al. (2020) indicate that e-service has an effect on satisfaction. This leads to the third $\left(\mathrm{H}_{3}\right)$ and fourth $\left(\mathrm{H}_{4}\right)$ hypothesis.

$\mathrm{H}_{3}$ : E-service quality significantly impact customer engagement

$\mathrm{H}_{4}$ : E-service quality significantly impact e-satisfaction

Satisfaction in using online services (e-satisfaction) is also an important determinant of customer engagement in digital era. The concept of satisfaction which is generally accepted contains an understanding to fulfill customer expectations (Martín-
Consuegra, Molina, \& Esteban, 2007). In other words, satisfaction can be realized when customer expectations can be met. This is in line with the explanation from Sumaedi et al. (2016) that customer satisfaction is a construct that represents a customer feeling favorable or unfavorable as a result from his assessment on the difference between the overall performance of the producer of goods or services and his expectations. Likewise, Jun, Yang, and Kim (2004) emphasize that consumer satisfaction is a comparison between expectations before buying with perceived product performance. Rifai and Wahyudi (2016) and VO et al. (2020) have shown that satisfaction affects customer engagement. Thus, the fifth hypothesis $\left(\mathrm{H}_{5}\right)$ can be formulated:

$\mathrm{H}_{5}$ : E-satisfaction significantly impacts customer engagement

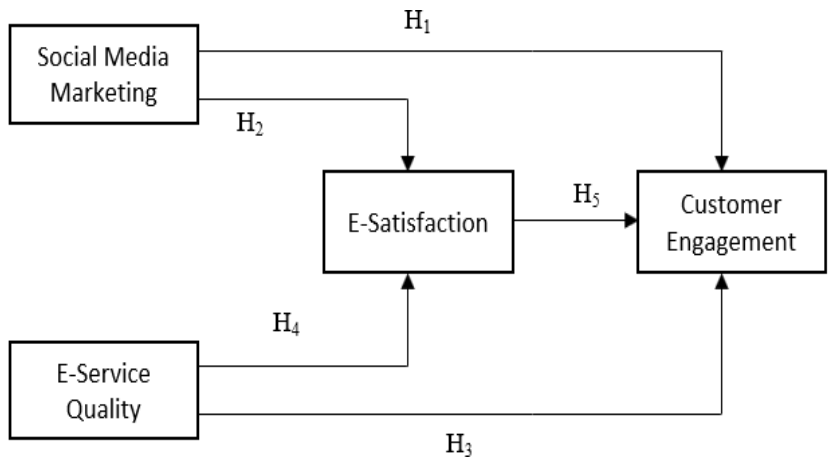

Figure 1 Theoretical Framework

Based on the theoretical framework(seeFigure 1), the research aims to examine the effect of social media marketing, e-service quality, and e-satisfaction on customer engagement. The results are expected to provide an overview the important role of social media as a media to support marketing and service activities, especially for Generation Z students, and ultimately can understand its contribution in increasing student satisfaction and engagement.

\section{METHODS}

The quantitative research aims to examine the effects of social media marketing, e-service quality, and e-satisfaction on customer engagement. The unit of analysis is the Generation $\mathrm{Z}$ of Binus students who become a follower of Gabung BINUS Instagram. The time horizon is cross-sectional, which means that data collection is done only once, where the research period is usually in days, weeks or even months. The research target population are 42.305 Generation $\mathrm{Z}$ students born in 1998-2010 with an age range between 16 to 22 years old (Hidayat \& Astuti, 2019). The research determines the sample size using the Slovin formula with an error rate of $10 \%$, and comes up with a sample of 100 respondents (Ryan, 2013). 
Data collection uses a 5-point Likert scale questionnaire. The social media marketing scale is developed based on five dimensions, namely interaction, sharing of content, accessibility and credibility (Elaydi, 2018; Kim \& Ko, 2010). E-service quality scale consists of the dimensions of reliability and responsiveness (Krishnadas \& Renganathan, 2019; Kumar \& Dash, 2015). E-satisfaction scale has a single dimension adapted from Boon-itt (2015); Tang, Tsai and $\mathrm{Wu}$ (2015). Meanwhile, the scale of customer engagement is developed based on the dimensions of enthusiasm, attention, and interaction (Rather \& Sharma, 2017). Each of these scales has been tested for validity and meets the requirements of the reliability test, where the social media marketing scale has alpha coefficient 0,857 , e-service quality 0,836 , e-satisfaction 0,794 , and customer engagement 0,821 . The data collection procedure is made using Google Form for making and delivering questionnaires to respondents with the consideration that the COVID-19 pandemic remains ongoing. In the first stage, the questionnaires are sent randomly via email or WhatsApp to 150 respondents identified as Binus students. After all the respondents' answers have been collected, a selection is carried out to choose samples according to predetermined criteria, namely students who are categorized as Generation Z.

Data analysis to test the research hypothesis uses path analysis with regression techniques. Path analysis makes it possible to test a model by determining the causal relationship between variables by applying multiple regression techniques (Bordens \& Abbott, 2011). SPSS software is used to analyze regression.

\section{RESULTS AND DISCUSSIONS}

In the early stages, as shown in Table 1 , the questionnaires are distributed to 150 respondents to be further selected according to the specified criteria, namely Generation Z students of Bina Nusantara who became followers of Gabung_BINUS on Instagram. Finally, 100 out of 150 respondents meet the criteria, with $43 \%$ male and $57 \%$ female.

Descriptive statistics in Table 2 are used to show the relationship between variables and an overview of the research variable scores. The relationships between variables are all significant at $99 \%$ level of confidence $(\alpha=0,01)$ with a correlation coefficient ranging from 0,625 to 0,750 . The strongest relationship is correlation between e-service quality and e-satisfaction, while the lowest is the relationship between e-satisfaction and customer engagement. Furthermore, the social media marketing variable scores are in the range between 2,5 to 5 , an average of 4,2 and a standard deviation of 0,5 . E-service quality ranges from 2,4 to 5 with a mean of 4,0 and a standard deviation of 0,6 . E-satisfaction is in the range of 2,5 to 5,0 with a mean of 4,3 and a standard deviation of 0,7 . Meanwhile, customer engagement has a minimum of 2,0 and a maximum of 5,0 with an average of 3,7 and a standard deviation of 0,7 .

Table 1 Respondent Profile

\begin{tabular}{lccccc}
\hline \multirow{2}{*}{ Respondent Profile } & & \multicolumn{2}{c}{ Male } & \multicolumn{2}{c}{ Female } \\
\cline { 3 - 6 } & & Frequency & $\mathbf{\%}$ & Frequency & $\mathbf{\%}$ \\
\hline Age & $16-22$ y.o. & 60 & 40,0 & 76 & 50,7 \\
& $23-26$ y.o. & 11 & 7,3 & 3 & 2,0 \\
\hline \multirow{2}{*}{ Follower of Gabung_BINUS Instagram } & Yes & 43 & 28,7 & 57 & 38,0 \\
& No & 23 & 15,3 & 27 & 18,0 \\
\hline
\end{tabular}

Table 2 Descriptive Statistics

\begin{tabular}{lcccc}
\hline \multicolumn{1}{c}{ Variables } & $\mathbf{1}$ & $\mathbf{2}$ & $\mathbf{3}$ & $\mathbf{4}$ \\
\hline 1. SMM & 1,000 & & & \\
2. ESQ & $0,682^{* *}$ & 1,000 & & \\
3. ES & $0,752^{* *}$ & $0,750^{* *}$ & 1,000 & \\
4. CE & $0,697^{* *}$ & $0,661^{* *}$ & $0,625^{* *}$ & 1,000 \\
\hline Minimum & 2,8 & 2,4 & 2,5 & 2,0 \\
Maximum & 5,0 & 5,0 & 5,0 & 5,0 \\
Mean & 4,2 & 4,0 & 4,3 & 3,7 \\
Standard Deviation & 0,5 & 0,6 & 0,7 & 0,7 \\
\hline \multicolumn{5}{c}{ ** p-value $<0,01$} \\
\end{tabular}

$\mathrm{SMM}=$ Social Media Marketing; ESQ = E-Service Quality; ES = E-Satisfaction; CE = Customer Engagement 
Table 3 Path Coefficients and T-Values

\begin{tabular}{lcccccc}
\hline \multirow{2}{*}{ Variables } & \multicolumn{3}{c}{ Model 1 $^{\mathbf{a}}$} & \multicolumn{3}{c}{ Model 2 $^{\mathbf{b}}$} \\
\cline { 2 - 7 } & Beta & T-Value & Sig. & Beta & T-Value & Sig. \\
\hline SMM & 0,449 & 5,645 & 0,000 & 0,430 & 4,005 & 0,000 \\
ESQ & 0,444 & 5,570 & 0,000 & 0,329 & 3,074 & 0,003 \\
ES & & & & 0,055 & 0,465 & 0,643 \\
$\mathrm{R}^{2}$ & 0,671 & & & 0,743 & & \\
\hline
\end{tabular}

${ }^{\mathrm{a} e}$-satisfaction as dependent variable;

${ }^{b}$ customer engagement as dependent variable

Table 3 summarizes the results of path coefficients and its significance calculated from statistical software of SPSS to test the hypothesis. The research has two structural equation models. The first model with dependent variable e-satisfaction is influenced by social media marketing and e-service quality, while the second model with the dependent variable of customer engagement is influenced by social media marketing, e-service quality, and e-satisfaction (see Figure 2).

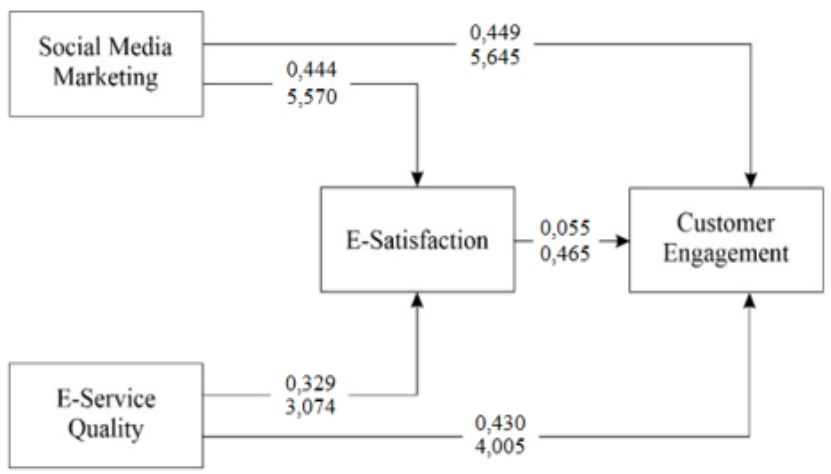

Figure 2 Path Diagram

The first model has a coefficient of determination $\left(\mathrm{R}^{2}\right)$ of 0,671 which shows that the contribution of social media marketing and e-service quality simultaneously is $67,1 \%$. The effect of social media marketing on e-satisfaction is indicated by path coefficient of 0,449 and $t$-value of 5,645 with significance or p-value of 0,000 . Significance value $<0,05$ indicated that social media marketing has a significant effect on e-satisfaction $\left(\mathrm{H}_{1}\right.$ is supported). Path coefficient from the effect of e-service quality on e-satisfaction is 0,444 with Sig. $0,000<0,05$, which mean e-service quality has a significant effect on e-satisfaction $\left(\mathrm{H}_{2}\right.$ is supported).

The second model shows a coefficient of determination $\left(\mathrm{R}^{2}\right)$ of 0,743 which mean that the simultaneous contribution of social media marketing, e-service quality, and e-satisfaction is $74,3 \%$. The effect of social media marketing on customer engagement has path coefficient of 0,430 and T-value 4,005 with Sig. $0,000<0,05$, so it can be concluded that social media marketing has a significant effect on customer engagement $\left(\mathrm{H}_{3}\right.$ is supported).

Furthermore, the effect of e-service quality on customer engagement is indicated by path coefficient of 0,329 and T-value 3,074 with Sig. $0,003<0,05$, which mean e-service quality has a significant effect on customer engagement ( $\mathrm{H}_{4}$ is supported). While for the effect of e-satisfaction on customer engagement, the test obtains path coefficient 0,055 and T-value 0,465 with Sig. $0,643>0,05$, so that e-satisfaction has no effect on customer engagement $\left(\mathrm{H}_{5}\right.$ is rejected).

The results indicate that social media marketing through Instagram is an important factor in influencing customer engagement and e-satisfaction of Generation $\mathrm{Z}$ students in higher education. It is implied that the ability of universities to effectively use social media for marketing has an impact in increasing student engagement and satisfaction when using campus' online services. The finding is understandable considering that Generation $\mathrm{Z}$ was born during the development of the digital era (Bernstein, 2015), known as digital natives who are technologically savvy (Priporas, Stylos, \& Fotiadis, 2017). Generation Z uses technology and digital devices extensively, and is close to social media in their daily lives (Ruangkanjanases $\&$ Wongprasopchai, 2017). Therefore, the use of social media for universities as a means of marketing is now a necessity, because Generation $\mathrm{Z}$ will dominate the number of students on campus. The use of social media is in accordance with the characteristics of students from Generation $\mathrm{Z}$ whose life cannot be separated from social media. Students have high expectation that universities can optimize the use of technology, so that the campus must be able to fulfill it.

The concept of satisfaction refers to the conformity between expectations and perceived of service or product (Jun et al., 2004; Martín-Consuegra et al., 2007; Sumaedi et al., 2016), so that the optimizing social media for promotion and providing services to students has reached their expectation, satisfaction, which results in increased attachment. These findings also support previous findings that show social media marketing has a significant effect on satisfaction (Hanaysha, 2017; Zoubi \& Al-Harazneh, 2019) and attachment (Ashley \& Tuten, 2015; Sashi, 2012).

The results also indicate that e-service quality has a significant effect on e-satisfaction and customer 
engagement. These findings confirm that the provision of quality of online services on campus will have a positive impact on increasing satisfaction and engagement. This is related to the characteristics of Generation Z, namely having a high involvement with digital technology on a daily basis. Therefore, students have high expectations for the availability of quality online services on campus. Students seem not interested in manual services that do not keep up with technological developments. Online services for students include enrollment, course delivery, payment, course support, and libraries (Sutarso \& Suharmadi, 2011). The campus does not ignore the growing trend in student demand as customers to provide services electronically (Ataburo, Muntaka, \& Quansah, 2017). Universities should be at the forefront of online activities (Kim-Soon, Rahman, \& Ahmed, 2014). The research also supports previous research which proves that e-service has a significant effect on satisfaction (Chang et al., 2009; Nasution, 2019; Ting et al., 2016; $\mathrm{VO}$ et al., 2020) and engagement (Dassanayake \& Senevirathne, 2018; VO et al., 2020).

Anotherresearchfindingshowsthate-satisfaction has no significant effect on engagement, so the satisfaction level with electronic services on campus does not have a significant impact on engagement. In the context of the research, student engagement does not depend on the level of satisfaction. It is more likely determined by the use of social media marketing and e-service by campus. Therefore, student from Generation $\mathrm{Z}$ will be more engaged if the use of digital technology is optimized in the campus environment to support services and learning activities. This is in accordance with Generation $\mathrm{Z}$ characteristics which is naturally engaged to digital technology that influences their lifestyle (Ruangkanjanases \& Wongprasopchai, 2017; Yussof et al., 2018).

\section{CONCLUSIONS}

The research aims to examine the effect of social media marketing, e-service quality, and e-satisfaction on customer engagement in higher education which specifically involves students from Generation $Z$. The findings of the research comes up with three highlights: 1) the positive and significant effect of social media marketing on e-satisfaction and student engagement, 2) the positive and significant effect of e-service quality on e-satisfaction and student engagement, and 3) no significant effect of e-satisfaction on student engagement. The research shows the important role of using digital technology in higher education which will determine the success and competitiveness of higher education institutions in the future along with the increasing number of students from Generation $\mathrm{Z}$. Digital technology is an important pillar in supporting higher education services and operations which in turn can increase student engagement.

The research has come up with an implication that higher education will try their best to build digital technology to support learning activities and campus operations. Generation $\mathrm{Z}$ has begun to dominate the number of students in higher education, and the number will certainly get bigger, so they must immediately build a digital-based smart campus. Conventional ways of carrying out campus activities must immediately be abandoned to meet the demands and expectations of students from Generation Z. Higher education management who generally comes from Generation X and Y should quickly adjust and understand the needs of Generation Z. Therefore, the development of digital technology will be the focus for higher education to be successful in a competitive environment.

The research contributes to provide an insight into higher education institutions in which using digital technology optimally and effectively is an important key to managing students from Generation Z. Digital technology that is well managed for social media marketing and services have a positive impact on student engagement. Furthermore, higher student engagement will make a positive contribution to academic achievement and support the career development of students in the future.

The research has a number of limitations that can be used as a basis for improvement for further research. The research scope is limited to Binus university as a private university and Generation $\mathrm{Z}$ students as a sample, so that the generalizability of the findings cannot be widely applied to other campuses. Having Generation $Z$ as a sample will be beneficial as the basis for further studies, however, it limits the generalizability of the research since there might be some students who come from the previous generation.

Further research needs to take the object of research on several campuses and a larger number of samples so that the results can be broadly generalized. In addition, it is suggested that the further research considers the use of different data analyzes, such as Structural Equation Modeling (SEM) to obtain a more comprehensive analysis.

\section{REFERENCES}

Ahlfeldt, S., Mehta, S., \& Sellnow, T. (2005). Measurement and analysis of student engagement in university classes where varying levels of PBL methods of instruction are in use. Higher Education Research and Development, 24(1), 5-20. https://doi.org/10.10 80/0729436052000318541.

Andrews, R., Boyne, G. A., Law, J., \& Walker, R. M. (2012). Strategic Management and Public Service Performance. New York: Palgrave Macmillan.

Armstrong, G. \& Kotler, P. (2015). Marketing: An Introduction. Essex: Pearson Education, Inc.

Ashley, C. \& Tuten, T. (2015). Creative strategies in social media marketing: An exploratory study of branded social content and consumer engagement. Psychology \& Marketing, 32(1), 15-27. https://doi. org/10.1002/mar. 
Ataburo, H., Muntaka, A. S., \& Quansah, E. K. (2017). Linkages among e-service quality, satisfaction, and usage of e-services within higher educational environments. International Journal of Business and Social Research, 7(3), 9-26. https://doi. org/10.18533/ijbsr.v7i3.1040.

Bannor, R., Asare, A. K., \& Bawole, J. N. (2017). Effectiveness of social media for communicating health messages in Ghana. Health Education, 117(4), 342-371. https://doi.org/10.1108/HE-06-2016-0024.

Bernstein, R. (2015, January 21). Move over millennials: Here comes Gen Z. AdAge. https://adage.com/article/ cmo-strategy/move-millennials-gen-z/296577.

Boon-itt, S. (2015). Managing self-service technology service quality to enhance e-satisfaction. International Journal of Quality and Service Sciences, 7(4), 373-391. https://doi.org/10.1108/ IJQSS-01-2015-0013.

Bordens, K. S. \& Abbott, B. B. (2011). Research design and methods: a process approach. In McGrawHill Education. https://doi.org/10.1088/09532048/11/3/002.

Bowden, J. L.-H. (2009). The process of customer engagement: a conceptual framework. Journal of Marketing Theory and Practice, 73(3), 52-68. https://doi.org/10.2753/MTP1069-6679170105.

Bullini Orlandi, L., Zardini, A., \& Rossignoli, C. (2020). Organizational technological opportunism and social media: The deployment of social media analytics to sense and respond to technological discontinuities. Journal of Business Research, 112, 385-395. https:// doi.org/10.1016/j.jbusres.2019.10.070.

Chang, H. H., Wang, Y. H., \& Yang, W. Y. (2009). The impact of e-service quality, customer satisfaction and loyalty on e-marketing: Moderating effect of perceived value. Total Quality Management and Business Excellence, 20(4), 423-443. https://doi. org/10.1080/14783360902781923.

Chen, L. \& Shi, J. (2015). Social support exchanges in a social media community for people living with HIV/ AIDS in China. AIDS Care - Psychological and Socio-Medical Aspects of AIDS/HIV, 27(6), 693-696. https://doi.org/10.1080/09540121.2014.991678.

Cheng, C. C. J. \& Shiu, E. C. (2019). How to enhance SMEs customer involvement using social media: The role of Social CRM. International Small Business Journal: Researching Entrepreneurship, 37(1), 2242. https://doi.org/10.1177/0266242618774831.

Chui, T. B., Ahmad, M. S. bin, Bassim, F. binti A., \& Zaimi, N. binti A. (2016). Evaluation of service quality of private higher education using service improvement matrix. Procedia - Social and Behavioral Sciences, 224(August), 132-140. https://doi.org/10.1016/j. sbspro.2016.05.417.

Dassanayake, H. C. \& Senevirathne, A. (2018). Impact of e-servicescapes on student engagement: mediating impact of experience quality. Asian Association of Open Universities Journal, 13(2), 203-222. https:// doi.org/10.1108/aaouj-11-2018-0024.

de Zubielqui, G. C. \& Jones, J. (2020). How and when social media affects innovation in start-ups. A moderated mediation model. Industrial Marketing Management, 85(February), 209-220. https://doi. org/10.1016/j.indmarman.2019.11.006.

Dissanayake, D. M. R., Siriwardana, A., \& Ismail, N. (2019). Social media marketing and customer engagement: A review on concepts and empirical contributions. Kelaniya Journal of Management, 8(1), 71. https:// doi.org/10.4038/kjm.v8i1.7592.

Đonlagić, S. \& Fazlić, S. (2015). Quality assessment in higher education using the servqual model. Management, 20(1), 39-57. https://www. researchgate.net/publication/282693142_Quality_ assessment_in_higher_education_using_the SERVQUALQ model.

El Alfy, S. \& Abukari, A. (2019). Revisiting perceived service quality in higher education: uncovering service quality dimensions for postgraduate students. Journal of Marketing for Higher Education, 30(1), 1-25. https://doi.org/10.1080/08841241.2019.16483 60

Elaydi, H. O. (2018). The effect of social media marketing on brand awareness through Facebook: An individualbased perspective of mobile services sector in Egypt. Open Access Library Journal, 5. https://doi. org/10.4236/oalib.1104977.

Elsharnouby, T. H. \& Mahrous, A. A. (2015). Customer participation in online co-creation experience: the role of e-service quality. Journal of Research in Interactive Marketing, 9(4), 313-336. https://doi. org/10.1108/JRIM-06-2014-0038.

Felix, R., Rauschnabel, P. A., \& Hinsch, C. (2017). Elements of strategic social media marketing: A holistic framework. Journal of Business Research, 70, 118126. https://doi.org/10.1016/j.jbusres.2016.05.001.

Fredricks, J. A., Blumenfeld, P. C., \& Paris, A. H. (2004). School engagement potential of the concept. Review of Educational Research, 74(1), 59-109.

Fredricks, J. A. \& McColskey, W. (2012). The measurement of student engagement: A comparative analysis of various methods and student self-report instruments. In S. L. Christenson, C. Wylie, \& A. L. Reschly (Eds.), Handbook of Research on Student Engagement (pp. 1-840). https://doi.org/10.1007/978-1-4614-2018-7.

Graffigna, G. \& Gambetti, R. C. (2015). Grounding consumer-brand engagement: A field-driven conceptualisation. International Journal of Market Research, 57(4), 605-630. https://doi.org/10.2501/ IJMR-2015-049.

Hanaysha, J. R. (2017). Impact of social media marketing, price promotion, and corporate social responsibility on customer satisfaction. Jindal Journal of Business Research, 6(2), 132-145. https://doi. org/10.1177/2278682117715359.

Hidayat, A. R. W. \& Astuti, S. R. T. (2019). Analisis pengaruh kesadaran merek, persepsi harga, desain web, terhadap minat beli pada Zenius Education (Studi pada perilaku generasi Z khusus siswa di Kabupaten Demak). Diponegoro Journal of Management, 8(2), 94-106. https://ejournal3.undip. ac.id/index.php/djom/article/view/25962.

Hollins, B. \& Shinkins, S. (2006). Managing Service 
Operations Design and Implementation. London: SAGE Publications, Inc.

Iankova, S., Davies, I., Archer-Brown, C., Marder, B., \& Yau, A. (2019). A comparison of social media marketing between B2B, B2C and mixed business models. Industrial Marketing Management, 81(January), 169-179. https://doi.org/10.1016/j. indmarman.2018.01.001.

Jackson, N. C. (2019). Managing for competency with innovation change in higher education: Examining the pitfalls and pivots of digital transformation. Business Horizons, 62(6), 761-772. https://doi. org/10.1016/j.bushor.2019.08.002.

Jun, M., Yang, Z., \& Kim, D. S. (2004). Customers' perceptions of online retailing service quality and their satisfaction. International Journal of Quality and Reliability Management, 21(8), 817-840. https:// doi.org/10.1108/02656710410551728.

Jung, J. (2020). The fourth industrial revolution, knowledge production and higher education in South Korea. Journal of Higher Education Policy and Management, 42(2), 134-156. https://doi.org/10.108 0/1360080X.2019.1660047.

Kavota, J. K., Kamdjoug, J. R. K., \& Wamba, S. F. (2020). Social media and disaster management: Case of the north and south Kivu regions in the Democratic Republic of the Congo. International Journal of Information Management, 52(January). https://doi. org/10.1016/j.ijinfomgt.2020.102068.

Keillor, B. D., Wilkinson, T. J., \& Thomas, A. R. (Eds.). (2007). Marketing in the 21 $1^{\text {st }}$ Century: New World Marketing. Westport: Greenwood Publishing Group, Inc.

Kemp, S. (2020, February 18). Digital 2020: Indonesia Data Reportal. https://datareportal.com/reports/ digital-2020-indonesia.

Kim-Soon, N., Rahman, A., \& Ahmed, M. (2014). E-service quality in higher education and frequency of use of the service. International Education Studies, 7(3), 1-10. https://doi.org/10.5539/ies.v7n3p1.

Kim, A. J., \& Ko, E. (2010). Impacts of luxury fashion brand's social media marketing on customer relationship and purchase intention. Journal of Global Fashion Marketing, 1(3), 164-171. https:// doi.org/10.1080/20932685.2010.10593068.

Krishnadas, R. \& Renganathan, R. (2019). Determinants of E-service quality features on customer satisfaction: A study among e-shoppers. Restaurant Business, 118(10), 76-87. https://doi.org/10.26643/ rb.v118i10.9035.

Kumar, A. \& Dash, M. K. (2015). E-service quality dimensions' effect on customers' willingness to buy: Structural equation modelling approach. International Journal of Services and Operations Management, 22(3), 287-303. https://doi. org/10.1504/IJSOM.2015.072313.

Marketing Science Institute. (2015). Understanding customer experience and behaviour. Research Priorities 2010-2012. http://image.sciencenet. cn/olddata/kexue.com.cn/upload/blog/ file/2010/9/201091515178616316.pdf
Martín-Consuegra, D., Molina, A., \& Esteban, Á. (2007). An integrated model of price, satisfaction and loyalty: An empirical analysis in the service sector. Journal of Product and Brand Management, 16(7), 459-468. https://doi.org/10.1108/10610420710834913

Nasution, H. (2019). The effect of e-service quality on e-loyalty through e-satisfaction on students of ovo application users at the faculty of economics. European Journal of Management and Marketing Studies, 4(1), 146-162. https://doi.org/10.5281/ zenodo. 3360880.

Ngai, E. W. T., Moon, K. K., Lam, S. S., Chin, E. S. K., \& Tao, S. S. C. (2013). Social media models, technologies, and applications: An academic review and case study. Social Media Models, Technologies, and Applications: An Academic Review and Case Study, 115(5), 769-802.

O’Neill, M. A. \& Palmer, A. (2004). Importanceperformance analysis: A useful tool for directing continuous quality improvement in higher education. Quality Assurance in Education, 12(1), 39-52. https://doi.org/10.1108/09684880410517423.

OECD. (2000). Student engagement at school: A sense of belonging and participation. In Results from PISA 2000. http://www.oecd.org/edu/school/ programmeforinernationalstudentassessmentpisa/33 689885.pdf.

Perry, J. L. \& Thomson, A. M. (2004). Civic Service: What Difference Does it Make? New York: M. E. Sharpe.

Pham, P. H. \& Gammoh, B. S. (2015). Characteristics of social-media marketing strategy and customerbased brand equity outcomes: a conceptual model. International Journal of Internet Marketing and Advertising, 9(4), 321-337. https://doi. org/10.1007/978-3-319-26647-3 87.

Priporas, C. V., Stylos, N., \& Fotiadis, A. K. (2017). Generation Z consumers' expectations of interactions in smart retailing: A future agenda. Computers in Human Behavior, 77, 374-381. https:// doi.org/10.1016/j.chb.2017.01.058.

Pucciarelli, F. \& Kaplan, A. (2016). Competition and strategy in higher education: Managing complexity and uncertainty. Business Horizons, 59(3), 311-320. https://doi.org/10.1016/j.bushor.2016.01.003.

Rather, R. A. \& Sharma, J. (2017). Customer engagement for evaluating customer relationships in hotel industry. European Journal of Tourism, Hospitality and Recreation, 8(1), 1-13. https://doi.org/10.1515/ ejthr-2017-0001.

Rifai, A. R. \& Wahyudi. (2016). The effort to create customer engagement on customer e-banking (Empirical studies on Bank BNI Regional Semarang). Jurnal Dinamika Manajemen, 7(2), 191-205. https:// journal.unnes.ac.id/nju/index.php/jdm/article/ view/8202/5620.

Ruangkanjanases, A. \& Wongprasopchai, S. (2017). Factors influencing customer adoption of mobile banking services: Empirical examination between generation $\mathrm{Y}$ and generation $\mathrm{Z}$ in Thailand. Advanced Science Letters, 23(1), 628-633. https://doi.org/10.1166/ asl.2017.7279. 
Ryan, T. P. (2013). Sample Size Determination and Power ( $1^{\text {st }}$ Ed.). New Jersey: John Wiley \& Sons, Inc.

Santos, J. (2003). E-service quality: A model of virtual service quality dimensions. Managing Service Quality: An International Journal, 13(3), 233-246. https://doi.org/10.1108/09604520310476490.

Sashi, C. M. (2012). Customer engagement, buyer-seller relationships, and social media. Management Decision, 50(2), 253-272. https://doi. org/10.1108/00251741211203551.

Sharma, V. \& Bharathi, V. (2013). Social Media for StartUps - An Effective Marketing Tool. SSRN Electronic Journal. https://doi.org/10.2139/ssrn.2333262.

Shawky, S., Kubacki, K., Dietrich, T., \& Weaven, S. (2019). Using social media to create engagement: a social marketing review. Journal of Social Marketing, 9(2), 204-224. https://doi.org/10.1108/ JSOCM-05-2018-0046.

So, K. K. F., King, C., \& Sparks, B. A. (2014). The role of customer engagement in building consumer loyalty to tourism brands. Journal of Travel Research, 55(1), 1-15. https://doi. org/10.1177\%2F0047287514541008.

Solomon, M. R., Marshall, G. W., \& Stuart, E. W. (2012). Marketing: Real People, Real Choices. New Jersey: Pearson Education, Inc.

Sultan, P. \& Wong, H. Y. (2013). Antecedents and consequences of service quality in a higher education context: A qualitative research approach. Quality Assurance in Education, 21(1), 70-95. https://doi. org/10.1108/09684881311293070.

Sumaedi, S., Bakti, I. G. M. Y., Rakhmawati, T., Astrini, N. J., Widianti, T., \& Yarmen, M. (2016). Factors influencing public transport passengers' satisfaction: a new model. Management of Environmental Quality: An International Journal, 27(5), 585-597. https://doi.org/10.1108/MEQ-05-2015-0084.

Sutarso, Y. \& Suharmadi, A. (2011). Promotion of e-technology-based services: A case study of e-service quality at a university in Indonesia. International Journal of Business \& Information, 6(1), 112-133. http://search.ebscohost.com/login.as px?direct $=$ true $\& d b=$ bth $\& A N=78202006 \&$ lang $=i t \&$ site $=$ ehost-live

Tang, T. W., Tsai, C. H., \& Wu, W. P. (2015). The relationships among trust, e-satisfaction, e-loyalty, and customer online behaviors. Proceedings of the International Conference on Electronic Business (ICEB), 1(2), 788-794. http://iceb.johogo.com/ proceedings/2005/788-794.pdf.

Thomas, L., Orme, E., \& Kerrigan, F. (2020). Student loneliness: The role of social media through life transitions. Computers and Education, 146. https:// doi.org/10.1016/j.compedu.2019.103754.

Ting, D. H., Abbasi, A. Z., \& Ahmed, S. (2020). Examining the mediating role of social interactivity between customer engagement and brand loyalty. Asia Pacific Journal of Marketing and Logistics. https:// doi.org/10.1108/APJML-10-2019-0576
Ting, O. S., Ariff, M. S. M., Zakuan, N., Sulaiman, Z., \& Saman, M. Z. M. (2016). E-Service quality, e-satisfaction and e-loyalty of online shoppers in business to consumer market; Evidence form Malaysia. IOP Conference Series: Materials Science and Engineering, 131(1). https://doi. org/10.1088/1757-899X/131/1/012012.

VO, N. T., Chovancová, M., \& Tri, H. T. (2020). The impact of e-service quality on the customer satisfaction and consumer engagement behaviors toward luxury hotels. Journal of Quality Assurance in Hospitality and Tourism, 21(5), 499-523. https://doi.org/10.108 0/1528008X.2019.1695701.

Wang, G., Zhang, W., \& Zeng, R. (2019). WeChat use intensity and social support: The moderating effect of motivators for WeChat use. Computers in Human Behavior, 91, 244-251. https://doi.org/10.1016/j. chb.2018.10.010.

Wang, W., Liang, Q., Mahto, R. V., Deng, W., \& Zhang, S. X. (2020). Entrepreneurial entry: The role of social media. Technological Forecasting and Social Change, 161(August). https://doi.org/10.1016/j. techfore.2020.120337.

Wu, N. \& Liu, Z. K. (2021). Higher education development, technological innovation and industrial structure upgrade. Technological Forecasting and Social Change, 162(October 2020). https://doi. org/10.1016/j.techfore.2020.120400.

Xu, X., Zeng, S., \& He, Y. (2017). The influence of e-services on customer online purchasing behavior toward remanufactured products. International Journal of Production Economics, 187(January), 113-125. https://doi.org/10.1016/j.ijpe.2017.02.019.

Yang, R. \& Che, T. (2020). Do social ties matter for purchase frequency? The role of buyers' attitude towards social media marketing. Computers in Human Behavior, 110(April). https://doi.org/10.1016/j. chb.2020.106376.

Yu, F. \& Schweisfurth, T. (2020). Industry 4.0 technology implementation in SMEs - A survey in the DanishGerman border region. International Journal of Innovation Studies, 4(3), 76-84. https://doi. org/10.1016/j.ijis.2020.05.001.

Yussof, F. M., Harun, A., Norizan, N. S., Durani, N., Jamil, I., \& Salleh, S. M. (2018). The influence of social media consumption on gen Z consumers' attitude. Journal of Fundamental and Applied Sciences, 10(6S), 1288-1299. https://www.ajol.info/index. php/jfas/article/view/171840.

Zeithaml, V. A., Parasuraman, A., \& Berry, L. L. (1990). Delivering Quality Service: Balancing Customer Perceptions and Expectation. New York: The Free Press.

Zoubi, F. H. \& Al-Harazneh, D. M. (2019). The impact of social media on customers' loyalty toward hotels in Jordan. International Journal of Business and Management, 14(5), 123. https://doi.org/10.5539/ ijbm.v14n5p123. 